\title{
Stan zachowania kompozycji i drzewostanu w zespole pałacowo-parkowym w Krzesimowie w województwie lubelskim
}

\author{
Kamila Lucyna Boguszewska \\ Wydział Budownictwa i Architektury, Politechnika Lubelska
}

\begin{abstract}
Streszczenie: Zespół pałacowo-parkowy w Krzesimowie zlokalizowany jest we wschodniej części gminy Mełgiew około 20 kilometrów od Świdnika. Obecnie składa się z części rezydencjonalnej - „pałacu na wyspie” i krajobrazowego parku.

Pierwsze wzmianki dotyczące majątku pochodzą z XVI wieku, jednak krajobrazowy park wraz z zachowanymi zabudowaniami powstał w I połowie XIX wieku kiedy to właścicielami dóbr była rodzina Stamirowskich.

W roku 2016 na potrzeby projektu rewaloryzacji zabytkowego założenia przeprowadzona została szczegółowa inwentaryzacja dendrologiczna oraz projekt gospodarki drzewostanem. Dokumentacja została wykonana po raz pierwszy na mapie do celów projektowych i objęła osiem hektarów parku wraz z alejami wyznaczającymi granice zespołu. Artykuł prezentuje wyniki powyższych badań w kontekście stanu zachowania drzewostanu i kompozycji parku.
\end{abstract}

Słowa kluczowe: Krzesimów, park, kompozycja, inwentaryzacja dendrologiczna

\section{Wstęp}

Zespół pałacowo-parkowy w Krzesimowie zlokalizowany jest w północno-wschodniej części gminy Mełgiew w odległości około 20 kilometrów od Świdnika. Pałac wraz z oficyną i historycznym parkiem usytuowany jest na wzgórzu w dolinie rzeki Stawek - Stoki.

Pierwsze wzmianki o miejscowości Krzesimów - Crzessimow pochodzą z XVI wieku, kiedy to założenie było własnością Jacobusa Brodskiego ${ }^{1}$.W wieku XVII majątek należał do rodziny Stamirowskich później zaś Brodskich. W jego skład wchodziło wówczas obronne fortalitium, które otoczone było ze wszystkich stron wodą ${ }^{2}$. Obrazują to nieco późniejsze plany takie jak: Carten von Westen Gallizien A. M. Hendesfelda z lat 1801-1804, czy fragment Mapy Kwatermistrzowskiej (1:126 000), z 1850 roku, Kol VI, Sec. X., kiedy to założenie pałacowo-parkowe było najpierw własnością rodziny Suchodolskich, później zaś Stamirowskich za których sprawą wzniesiony został klasycystyczny pałac. Nieco później na wschód od pałacu wybudowana została oficyna. Dopełnieniem założenia "na wyspie" był krajobrazowy park zlokalizowany po stronie wschodniej, a rozdzielony od reszty kanałami.

W wyniku zawirowań dziejowych zespół pałacowo-parkowy zmieniał właścicieli. Od roku 1907 stał się własnością Józefa Dreckiego, później zaś jego syna Kazimierza ostatniego właściciela Krzesimowa ${ }^{3}$. Po Il wojnie światowej majątek został przejęty przez Państwowe Gospodarstwo Rolne, później zaś w latach 70 XX wieku przez Państwowy Zakład Opieki Społecznej. Do chwili obecnej park nie doczekał się kompleksowej rewaloryzacji. Obecnie częściowo zatarte zostały elementy poszczególnych wnętrz krajobrazowych, zmianom uległy także stosunki wodne i własnościowe ${ }^{4}$ uniemożliwiając tym samym pełną rekonstrukcję historycznego układu

1 M. Kseniak, Parki i ogrody dworskie w Województwie Lubelskim cz. I, Od Trawnik do Łęcznej wzdtuż Wieprza, PTTK Zarząd Wojewódzki, Lublin 1981, s. 53-57

2 E. Podkościelny, A. Chrzanowska, Krzesimów gmina Mełgiew, woj. lubelskie, Projekt rewaloryzacji zabytkowego założenia pałacowo-parkowego, Warszawa - Lublin, 2003, s. 5

3 Ibid, s. 5-6

4 Wojewódzki Urząd Ochrony Zabytków, Wytyczne konserwatorskie do planowanego remontu budynków i rewaloryzacji parku., IN.5183.30.1.2016 
wodnego stanowiącego integralny element założenia. Historyczne założenie pałacowo-parkowe w Krzesimowie objęte jest ochroną konserwatorską (wpis do rejestru zabytków woj. lubelskiego nr A/740).

\section{Stan badań}

Stan zachowania założenia pałacowo-parkowego w Krzesimowie był przedmiotem badań już od drugiej połowy XX wieku. O parku towarzyszącym założeniu rezydencjonalnym pisał M. Kseniak w publikacji dotyczącej parków i ogrodów dworskich w województwie lubelskim (1981) w który przedstawiona została pokrótce historia zespołu oraz ówczesny stan zachowania założenia. Autor przedstawił także listę drzew rzadszych, oraz tych mających wpływ na układ kompozycyjny parku oraz listę drzew pomnikowych w liczbie 10 sztuk z określeniem gatunków i obwodów pni.

W roku 1996 przeprowadzono „Ekspertyzę stanu zdrowotnego drzew parku w Krzesimowie, gmina Metgiew, województwo lubelskie" autorstwa R. Wojewody, J. Sposoba i E. Chęcia. W ramach prac sporządzono szczegółową inwentaryzację dendrologiczną drzewostanu przy pałacu oraz ogólną całego założenia parkowego wraz z wytycznymi pielęgnacyjnymi. Opracowanie to było podstawą zaktualizowanego opracowania wykonanego przez E. Podkościelny w roku 2002 czego wynikiem była praca wraz z A. Chrzanowską pt. Krzesimów gmina Metgiew, woj. lubelskie, Projekt rewaloryzacji zabytkowego założenia pałacowo-parkowego, Warszawa - Lublin znajdująca się obecnie w zbiorach Wojewódzkiego Urzędu Ochrony Zabytków. Autorki podeszły kompleksowo do zespołu pałacowo-parkowego. Na potrzeby pracy przeprowadzone zostały badania historyczne, szereg analiz przedprojektowych, wizje lokalne oraz aktualizacje inwentaryzacji drzewostanu wraz z dendrochronologią i wytycznymi konserwatorskimi do prac projektowych. Sam projekt nie zawierał rozwiązań technicznych proponował jedynie kierunki działań i kreślił koncepcyjny plan rewaloryzacyjny założenia pałacowo-parkowego. $\mathrm{Na}$ obszarze objętym opracowaniem Autorki zinwetaryzowano 857 sztuk drzew, zaś skład gatunkowy określony został na 33 gatunki wraz z określeniem liczby sztuk. W pracy przedstawione zostały dane dotyczące starodrzewu reprezentowanego przez 16 gatunków drzew wraz z określeniem ich szacunkowego wieku i układów przestrzennych w parku.

W roku 2011 przeprowadzona została inwentaryzacja zespołu pałacowo-parkowego w Krzesimowie gm. Mełgiew przez M. Dudkiewicz (rkps. W archiwum Zakładu Dendrologii i Terenów zieleni Uniwersytetu Przyrodniczego w Lublinie) w wyniku której opracowano artykuł pt. Koncepcja rewaloryzacji zabytkowego założenia pałacowo-parkowego w Krzesimowie w gminie Mełgiew (2013), Kompozycja i drzewostan parku kaligraficznego w Krzesimowie gm. Mełgiew (2013). Szczegółowa inwentaryzacja objęła jedynie otoczenie pałacu i budynki folwarczne wraz z terenem nad stawami. W wyniku tych badań zinwentaryzowano 396 drzew i 40 krzewów. Autorka zaklasyfikowała przebadane egzemplarze do 27 gatunków, zaś krzewy do 15. Pod względem liczebności przeważała Tilia cordata Mill. (88 szt,), Acer platanoides L. (40 sz.) i Robinia Pseudoacacia L. 26 sztuk. Pozostała część parku objęta została inwentaryzacja ogólną czego wynikiem była przewaga gatunkowa Alnus glutinosa Moench, Carpinus Betulus L. i Populus alba L. ${ }^{5}$

Autorka zaproponowała także koncepcję rewaloryzacji założenia niestety niemożliwą do zrealizowania. Dyskusyjna jest próba odtworzenia systemu stawów otaczających rezydencję na wyspie co nie ma racji bytu przy obecnych stosunkach własnościowych oraz poziomie wód gruntowych.

Podstawą wyżej wymienionych opracowań nie była mapa do celów projektowych. Dopiero w roku 2016 przeprowadzona została szczegółowa inwentaryzacja drzewostanu oraz projekt gospodarki drzewostanem przez zespół K. Boguszewska, M. Boguszewska, M. Boruch, R. Chyżewska, J. Mysliwiec. Zakresem opracowania objęto część działki o numerze ewidencyjnym 782/1 o powierzchni 8 ha stanowiący główną część założenia pałacowo-parkowego, tj. wyspę z pałacem i oficyną oraz przylegający do niej od strony wschodniej park krajobrazowy. Dodatkowo zinwentaryzowane zostały aleje i szpalery będące poza granicami opracowania tworzące jednak spójną całość z badanym założeniem. 


\section{Metodyka prowadzonych badań}

Wszelkie prace inwentaryzacyjne wykonano w zakresie obowiązującym przy tego typu opracowaniach, metodami ogólnie przyjętymi w dendrometrii. Teren opracowania został podzielony na cztery sektory.

Inwentaryzacją szczegółową objęto drzewa o średnicach pnia powyżej $60 \mathrm{~cm}$, jedynie w sektorze pierwszym, w najbliższym otoczeniu pałacu, czyli na tzw. wyspie, inwentaryzacji poddano również drzewa, których średnica pnia nie przekraczała $60 \mathrm{~cm}$. Określono ich lokalizację i naniesiono ją na podkład przygotowany w wyniku pomiarów geodezyjnych. Numerowanie roślin rozpoczęto kolejno w wyznaczonych sektorach, co przedstawiono na mapie. Gatunki określono na podstawie indywidualnych cech morfologicznych, w oparciu o literaturę dendrologiczną. Dokonano podstawowych pomiarów dendrometrycznych. Za pomocą taśmy mierniczej, zmierzony został obwód pnia na wysokości $130 \mathrm{~cm}$ ponad poziomem gruntu (pierśnica), z dokładnością do $1 \mathrm{~cm}$, oraz średnica rzutu korony, z dokładnością do $1 \mathrm{~m}$. Pomiaru wysokości drzew dokonano za pomocą wysokościomierza listewkowego, z dokładnością do $1 \mathrm{~m}$. W przypadku krzewów dokonano rozpoznania gatunkowego oraz zaznaczono ich umiejscowienie na rysunku inwentaryzacyjnym.

W projekcie gospodarki drzewostanem ocenie poddano stan zachowania drzewostanu, zasady porządkowania istniejącego układu zadrzewień i sposoby zabezpieczenia wraz z proponowanymi zabiegami pielęgnacyjnymi.

W określaniu wieku drzew posłużono się tabelą wiekową drzew opracowaną przez prof. Longina Majdeckiego 1980/1986.

\section{Układ kompozycji parku pałacowego}

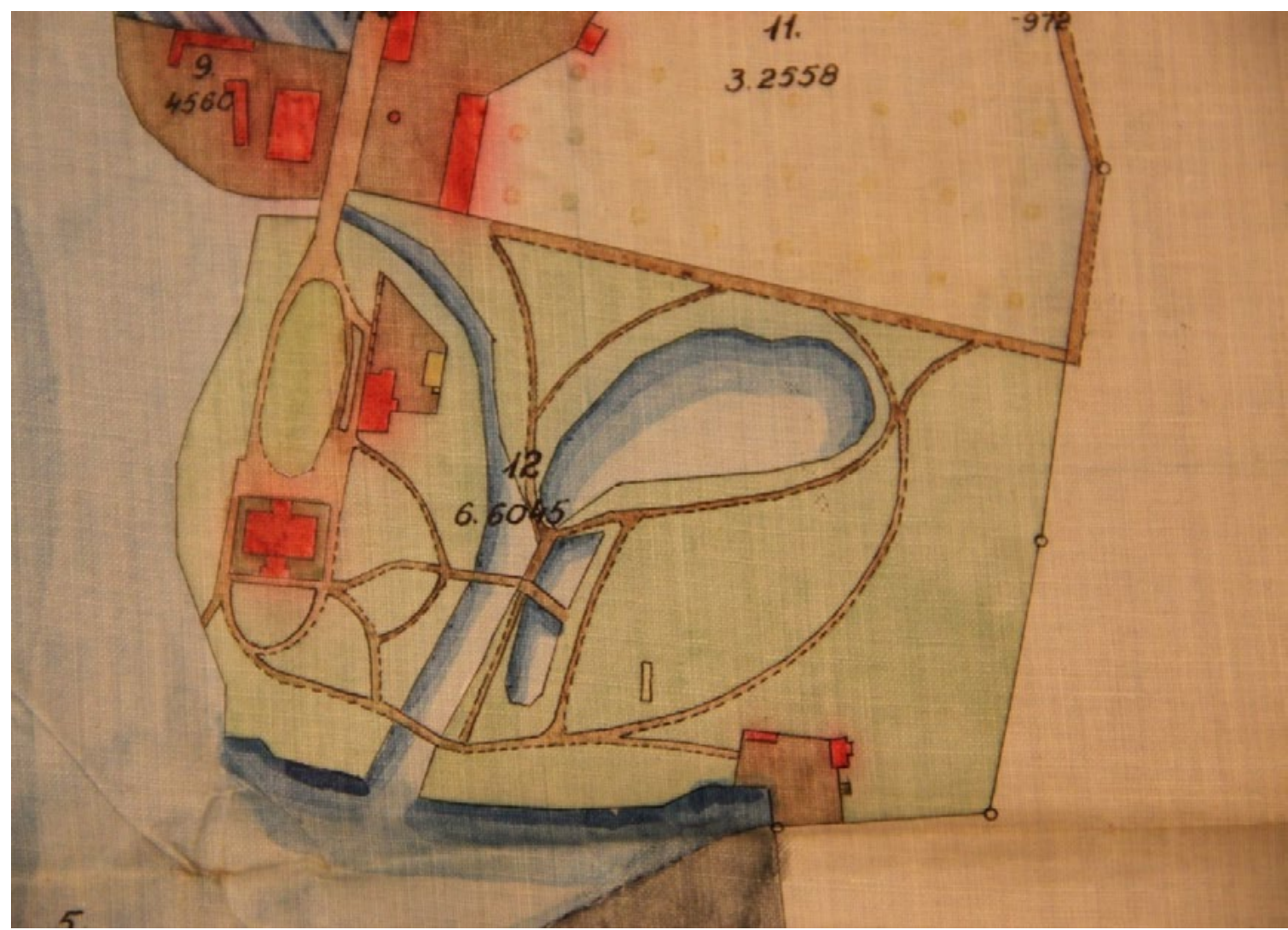

Ryc. 1. Zespół pałacowo-parkowy w Krzesimowie - plan parku, plan z 1935 roku, (archiwum Sądu Okręgowego w Lublinie, Lublin-Wschód. 


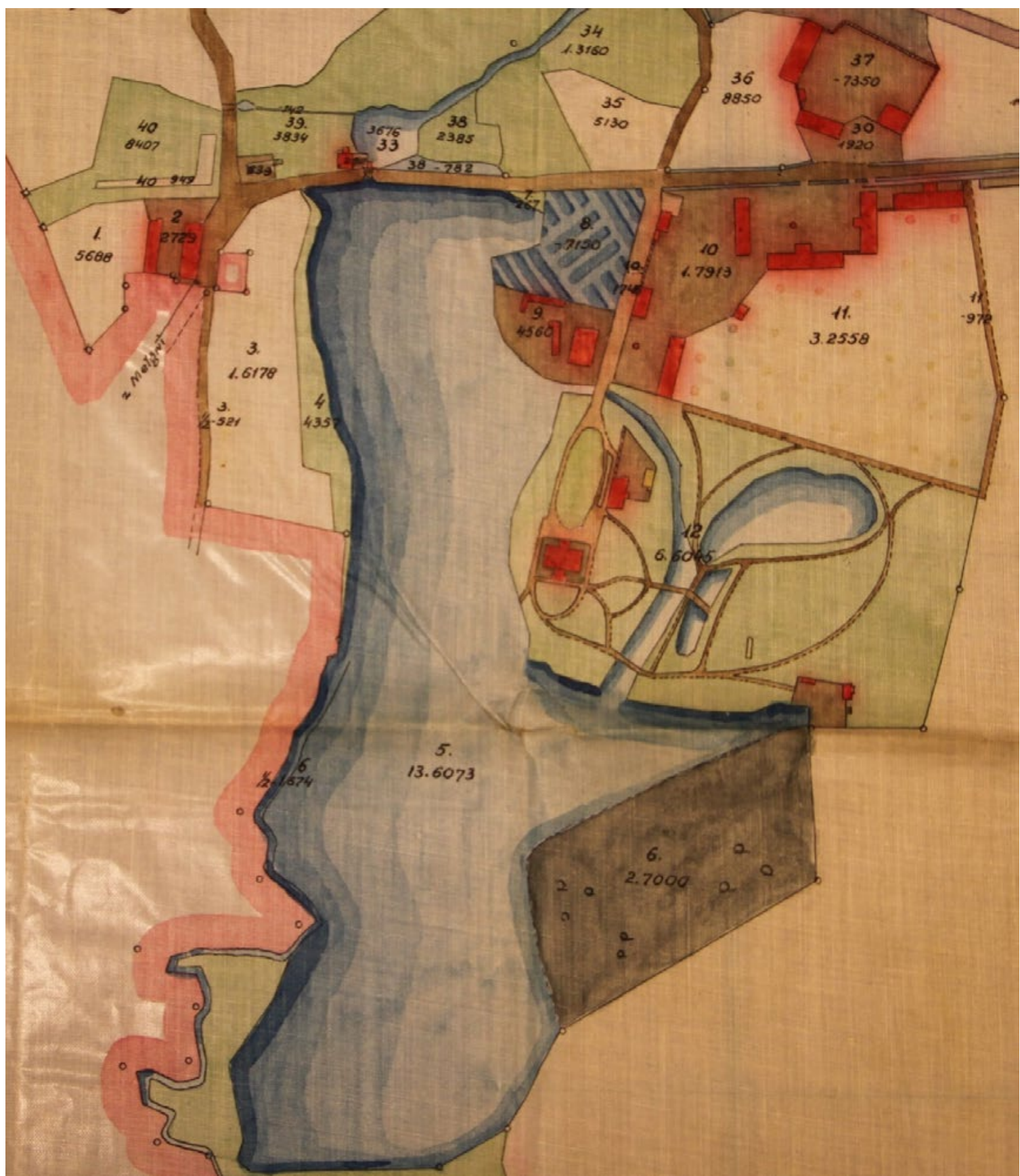

Ryc. 2. Zespół pałacowo-parkowy w Krzesimowie - plan całego zespołu wraz z przyległymi folwarkami z 1935 roku, (archiwum Sądu Okręgowego w Lublinie, Lublin-Wschód).

Palace-park complex in Krzesimow, plan of whole complex with granges from 1935, ( archive District Court in Lublin, Lublin-East)

Park krajobrazowy w Krzesimowie powstawał w I połowie XIX wieku za sprawą rodziny Stamirowskich ${ }^{6}$. Od północy graniczył on z sadami, od wschodu jego granica wyznaczona została poprzez linię alei grabowych i lipowych zaś od południa i zachodu park i wyspa otoczone były stawami. Na podstawie zachowanego Planu gruntów majątku Krzesimów autorstwa mierniczego przysięgtego Leopolda Pajdowskiego z roku 1935 można 
zauważyć, że założenie podzielone było na dwie części: rezydencji „na wyspie“ poprzedzonej 150 metrową aleją (pierwotnie lipową) i parku krajobrazowego.

Granice parku wyznaczone były wówczas od północy aleją grabową i zabudowaniami folwarcznymi i sadem - widocznymi na planie, od wschodu uprawami (niegdyś ogrodem warzywnym) zaś od zachodu i południa „wielkim stawem". Część rezydencjonalna na wyspie składała się z pałacu i budynku oficyny poprzedzonych eliptycznym gazonem. Park posiadał układ parku kaligraficznego. Jego kompozycja oparta była na powiązanych ze sobą wnętrzach krajobrazowych, osiach i otwarciach. Na jego terenie znajdowało się wówczas pięć stawów. Był on także w całości ogrodzony. Przez dwa kanały dzielące majątek na dwie części poprowadzone były arkadowe mostki.

Elementy małej architektury reprezentowane były także przez pawilon oranżerii oraz dom ogrodnika wraz ze szklarnią. Budynki te usytuowane niegdyś w południowej części parku nie zachowały się do chwili obecnej. Podobnie zresztą jak jakakolwiek ikonografia dotycząca zespołu pałacowo-parkowego, która mogłaby stanowić punkt wyjścia do projektu rewaloryzacji parku.

Na planie nie naniesiono roślinności. Poszczególne wnętrza krajobrazowe czytelne są na podstawie zaznaczonych przebiegów ścieżek parkowych oraz systemu kanałów wodnych i stawów.

Obecnie na terenie parku występuje 37 gatunków drzew, niektóre z nich posiadają status pomników przyrody i datowane są na ponad 250 lat $^{7}$.

a

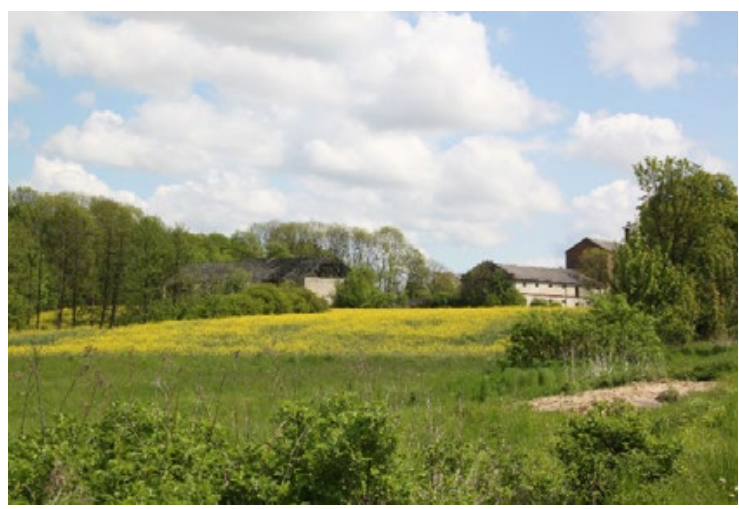

C

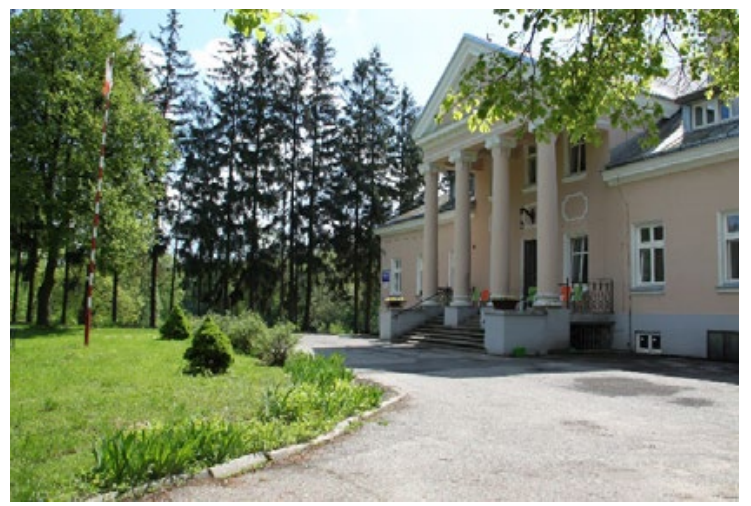

b

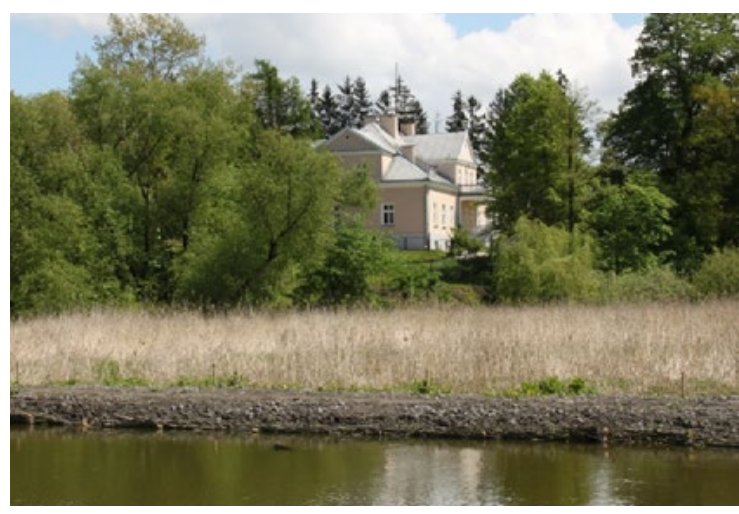

d

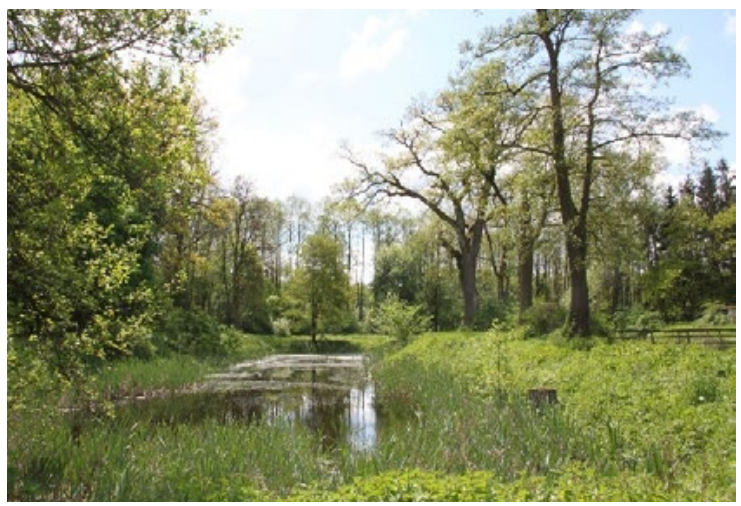

Ryc. 3. Zespół pałacowo-parkowy w Krzesimowie: a - widok na folwark „za drogą", b - wzgórze krzesimowskie - widok na pałac od strony dawnego wielkiego stawu, c - elewacja frontowa pałacu, d-park krajobrazowy widok na pomnikowe drzewa i pozostałości stawów ogrodowych, (2016, fot. Autor).

Palace-park complex in Krzesimow: a - grange, b - hill in Krzesimow - view on palace from side of big pond, c - the main facade of palace, $d$ - park with monumental trees and old garden ponds (2016, photo by author). 


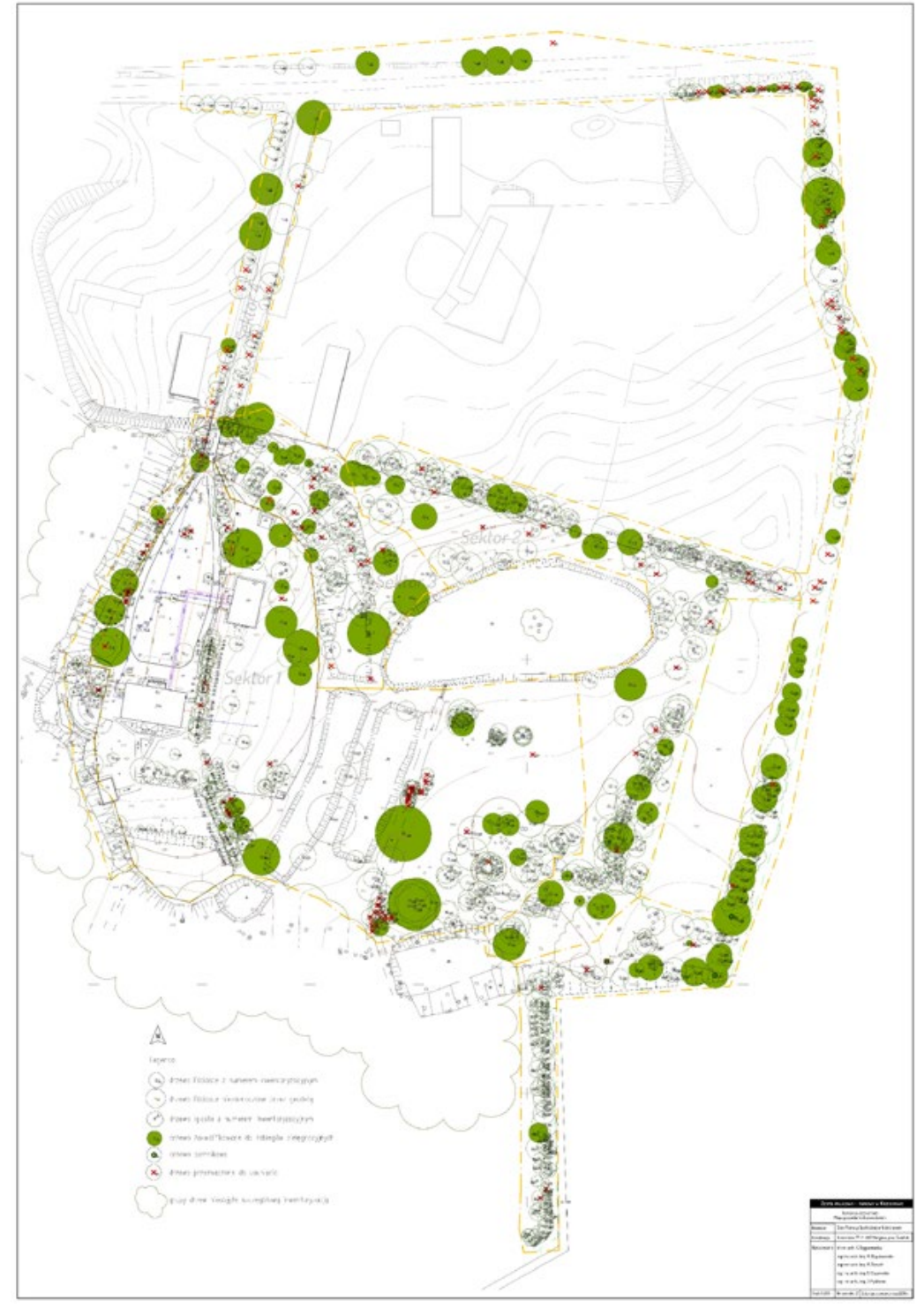

Ryc. 4. Zespół pałacowo-parkowy w Krzesimowie - projekt gospodarki drzewostanem, (maj 2016, Archiwum własne)

Palace-park complex in Krzesimow tree management (may 2016, Archive by Author)

\section{Wyniki inwentaryzacji dendrologicznej}

Ze względu na rozległość obszaru opracowania teren podzielony został na cztery części. W wyniku przeprowadzonych badań dokonano oględzin 1023 drzew. Na omawianym terenie zinwentaryzowano 38 gatunków drzew liściastych i iglastych. Zestawienie szczegółowe obejmuje 1023 pozycji. W sektorze pierwszym zinwentaryzowano 275 drzew, w sektorze drugim - 247 drzewa, trzecim - 174 zaś w czwartym - 317.

Największą liczebność wykazują drzewa gatunku: lipa drobnolistna (Tilia cordata Mill.), grab pospolity (Carpinus betulus L.), świerk pospolity (Picea abies (L.) H.Karst), klon zwyczajny (Acer platanoides L.), dąb szypułkowy (Quercus robur L.), olsza czarna (Alnus glutinosa Gaertn.), klon jawor (Acer pseudoplatanus L.) oraz robinia akacjowa (Robinia pseudoacacia L.).

Podrost drzewostanu, czyli samosiewy niepodlegające spisowi inwentaryzacyjnemu, składa się z dziewięciu gatunków drzew i krzewów takich jak: bez czarny (Sambucus nigra L.), leszczyna pospolita (Corylus avellana L.), śnieguliczka biała (Symphoricarpos albus Duhamel), klon zwyczajny (Acer platanoides L.), olsza czarna (Alnus glutinosa Gaertn.), robinia akacjowa (Robinia pseudoacacia L.), grab pospolity (Carpinus betulus L.), lipa 
drobnolistna (Tilia cordata Mill.), czeremcha zwyczajna (Prunus padus L.) i śliwa domowa (Prunus domestica L. subsp. syriaca (Borkh.)).

Zadrzewienia sąsiadujące z terenem objętym szczegółową inwentaryzacją dendrologiczną zinwentaryzowano jako grupy i zaznaczono na mapie inwentaryzacyjnej.

W grupach zadrzewień rozpoznano następujące gatunki: bez czarny (Sambucus nigra L.), klon zwyczajny (Acer platanoides L.), klon jawor (Acer pseudoplatanus L.), olsza czarna (Alnus glutinosa Gaertn.), grab pospolity (Carpinus betulus L.), świerk pospolity (Picea abies (L.) H.Karst), czeremcha zwyczajna (Prunus padus L.), robinia akacjowa (Robinia pseudoacacia L.), wierzba biała (Salix alba L.), lipa drobnolistna (Tilia cordata Mill.). Na terenie zespołu pałacowo-parkowego w Krzesimowie zinwentaryzowano dziewięć pomników przyrody: sześć sztuk w sektorze pierwszym i trzy sztuki w sektorze czwartym? .

Tabela 1. Zestawienie drzew pomnikowych na terenie opracowania stan na maj $2016 \mathrm{r}$.

Mapping of monumental trees at the site of the design area in May 2016.

\begin{tabular}{|c|c|c|c|}
\hline Gatunek drzewa & Pierśnica & $\begin{array}{c}\text { Wiek drzewa określony } \\
\text { według tabeli } \\
\text { wiekowej Longina } \\
\text { Majdeckiego }\end{array}$ & Lokalizacja \\
\hline $\begin{array}{l}\text { Dąb szypułkowy } \\
\text { (Quercus robur L.) }\end{array}$ & $468 \mathrm{~cm}$ & 325 & Park krajobrazowy \\
\hline $\begin{array}{l}\text { Dąb szypułkowy } \\
\text { (Quercus robur L.) }\end{array}$ & $524 \mathrm{~cm}$ & 364 & Park krajobrazowy \\
\hline $\begin{array}{l}\text { Lipa drobnolistna } \\
\text { (Tilia cordata Mill.) }\end{array}$ & $420 \mathrm{~cm}$ & 175 & $\begin{array}{c}\text { Część rezydencjonalna } \\
\text { „na wyspie” }\end{array}$ \\
\hline $\begin{array}{l}\text { Lipa drobnolistna } \\
\text { (Tilia cordata Mill.) }\end{array}$ & $376 \mathrm{~cm}$ & 156 & $\begin{array}{c}\text { Część rezydencjonalna } \\
\text { „na wyspie” }\end{array}$ \\
\hline $\begin{array}{l}\text { Lipa drobnolistna } \\
\text { (Tilia cordata Mill.) }\end{array}$ & $\begin{array}{c}256 \mathrm{~cm} / \text { brak tablicy } \\
\text { znamionowej/informacja } \\
\text { od Dyrektora DPS }\end{array}$ & 106 & $\begin{array}{c}\text { Część rezydencjonalna } \\
\text { „na wyspie” }\end{array}$ \\
\hline $\begin{array}{l}\text { Lipa drobnolistna } \\
\text { (Tilia cordata Mill.) }\end{array}$ & $377 \mathrm{~cm}$ & 156 & $\begin{array}{c}\text { Część rezydencjonalna } \\
\text { "na wyspie" }\end{array}$ \\
\hline $\begin{array}{l}\text { Lipa drobnolistna } \\
\text { (Tilia cordata Mill.) }\end{array}$ & $590 \mathrm{~cm}$ & 245 & Park krajobrazowy \\
\hline $\begin{array}{l}\text { Lipa drobnolistna } \\
\text { (Tilia cordata Mill.) }\end{array}$ & $\begin{array}{l}\quad 450 \mathrm{~cm} \\
\text { brak tabliczki } \\
\text { znamionowej }\end{array}$ & 187 & Park krajobrazowy \\
\hline $\begin{array}{l}\text { Lipa drobnolistna } \\
\text { (Tilia cordata Mill.) }\end{array}$ & $\begin{array}{l}- \\
\text { Egzemplarz martwy } \\
\text { powalony }\end{array}$ & - & Park krajobrazowy \\
\hline
\end{tabular}

8 M. Kseniak w publikacji (1981) pt. Parki i ogrody dworskie w Województwie Lubelskim cz. I, Od Trawnik do Łęcznej wzdłuż Wieprza, podaje liczbę 10 drzew pomnikowych na obszarze parku, liczbe jedenastu drzew pomnikowych podaje E. Podkościelny (2002) natomiast w publikacji Śladami przeszłości gminy Mełgiew, Zespół pałacowo-parkowy w „Dolina Krzyży: w Krzesimowie, Krzesimów 2016, s. 36, liczba drzew pomnikowych określona została na 11 sztuk - cztery w części rezydencjonalnej (w tym jedno drzewo zostało usunięte) i siedem w części krajobrazowej parku. M. Dudkiewicz ( 2013) pisze o ośmiu drzewach pomnikowych na inwentaryzowanym terenie.

9 K. Boguszewska, M. Boguszewska, R. Chyżewska, M. Boruch, J. Myśliwiec, Zespół pałacowo-parkowy w Krzesimowie część pierwsza Szczegółowa inwentaryzacja dendrologiczna, s. 1-9, maj 2016, archiwum autora 


\section{Drzewa pomnikowe}

Na badanym terenie zinwentaryzowano dziewięć drzew będących pomnikami przyrody: dwa dęby szypułkowe (Quercus robur L.) oraz cztery lipy drobnolistne (Tilia cordata Mill.) znajdujące się w sektorze pierwszym na obszarze parku przy rezydencji oraz trzy lipy drobnolistne (Tilia cordata Mill.) znajdujące się w sektorze czwartym na terenie parku krajobrazowego.

Dęby pomnikowe zlokalizowane są w części krajobrazowej parku, na przeciwległych brzegach jednego ze stawów parkowych. Oba drzewa mają ponad trzysta lat. Charakteryzują się one dobrym stanem zdrowotnym choć posiadają pewne cechy świadczące o ich wieku, takie jak: złamany współprzewodnik, ślady po zabiegach pielęgnacyjnych, narośla, złamane pojedyncze konary, ubytki kory czy niewielkie wypróchnienia pnia. Drzewa wykazują się jednak dobrą żywotnością. Dąb o obwodzie $524 \mathrm{~cm}$ jest najstarszym drzewem na terenie całego założenia liczy bowiem około 364 lata i mógł zostać zasadzony w czasach kiedy właścicielami majątku była rodzina Stamirowskich.

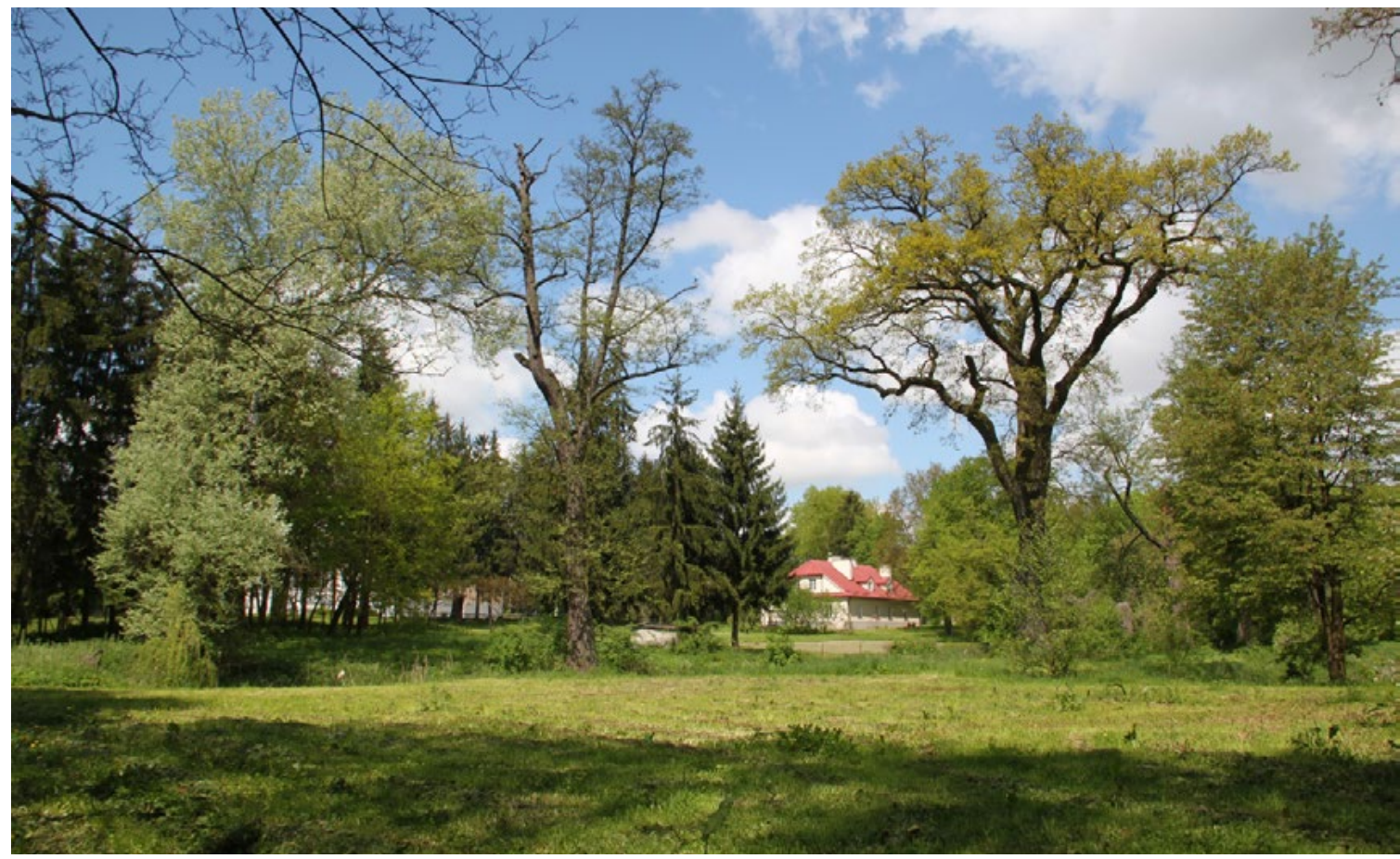

Ryc. 5. Quercus robur L., będące pomnikiem przyrody. Fot. Kamila Boguszewska, 2016.

Quercus robur L.,monumental tree photo by Kamila Boguszewska, 2016.

W najbliższym otoczeniu pałacu zlokalizowane zostały cztery lipy drobnolistne (Tilia cordata Mill.), które są pomnikami przyrody. Ich stan zachowania jest zróżnicowany od dobrego i średniego. W chwili obecnej zauważalne są istotne zmiany w ich budowie, takie jak: ubytki kory, martwe konary, ślady po owadach, ślady po zabiegach pielęgnacyjnych, odrosty korzeniowe i pniowe, narośla, liczne dziuple, oraz wysięgi korzeniowe.

Lipa zlokalizowana przy samym pałacu (o pierśnicy $376 \mathrm{~cm}$ ) ma mocno zachwianą statykę (w czerwcu 2016 obłamał się jeden z przewodników). Niezbędne są cięcia pielęgnacyjne mające na celu usunięcie istniejącego posuszu w koronie, obłamanych i martwych konarów wraz z odrostami.

Drzewa te mają ponad 150 lat i sadzone były prawdopodobnie w II połowie XIX wieku, kiedy właścicielami majątku była rodzina Plewińskich. Okresu największej prosperity majątku w Krzesimowie.

Drzewa pomnikowe na terenie parku krajobrazowego reprezentowane są w większości przez lipy drobnolistne (Tilia cordata Mill.). Na terenie sektora czwartego, drzewo o pierśnicy $590 \mathrm{~cm}$ wymaga zabiegów pielęgnacyjnych polegających na usunięciu posuszu, martwych gałęzi, konarów oraz odrostów pniowych i korzeniowych. Ogólna kondycja drzewa jest dobra. Lipa drobnolistna (Tilia cordata Mill.), w tym samym rejonie (o obwodzie 
$450 \mathrm{~cm}$ ), wymaga zabiegu pielęgnacyjnego jakim jest usunięcie wyłamanego konaru. Ponadto należy umieścić w widocznym miejscu tabliczkę znamionową. Ostatnim drzewem pomnikowym jest egzemplarz martwy - bez tabliczki znamionowej, rozłupany na wiele fragmentów. Określenie jego wymiarów było niemożliwe. Drzewo to kwalifikuje się do usunięcia.

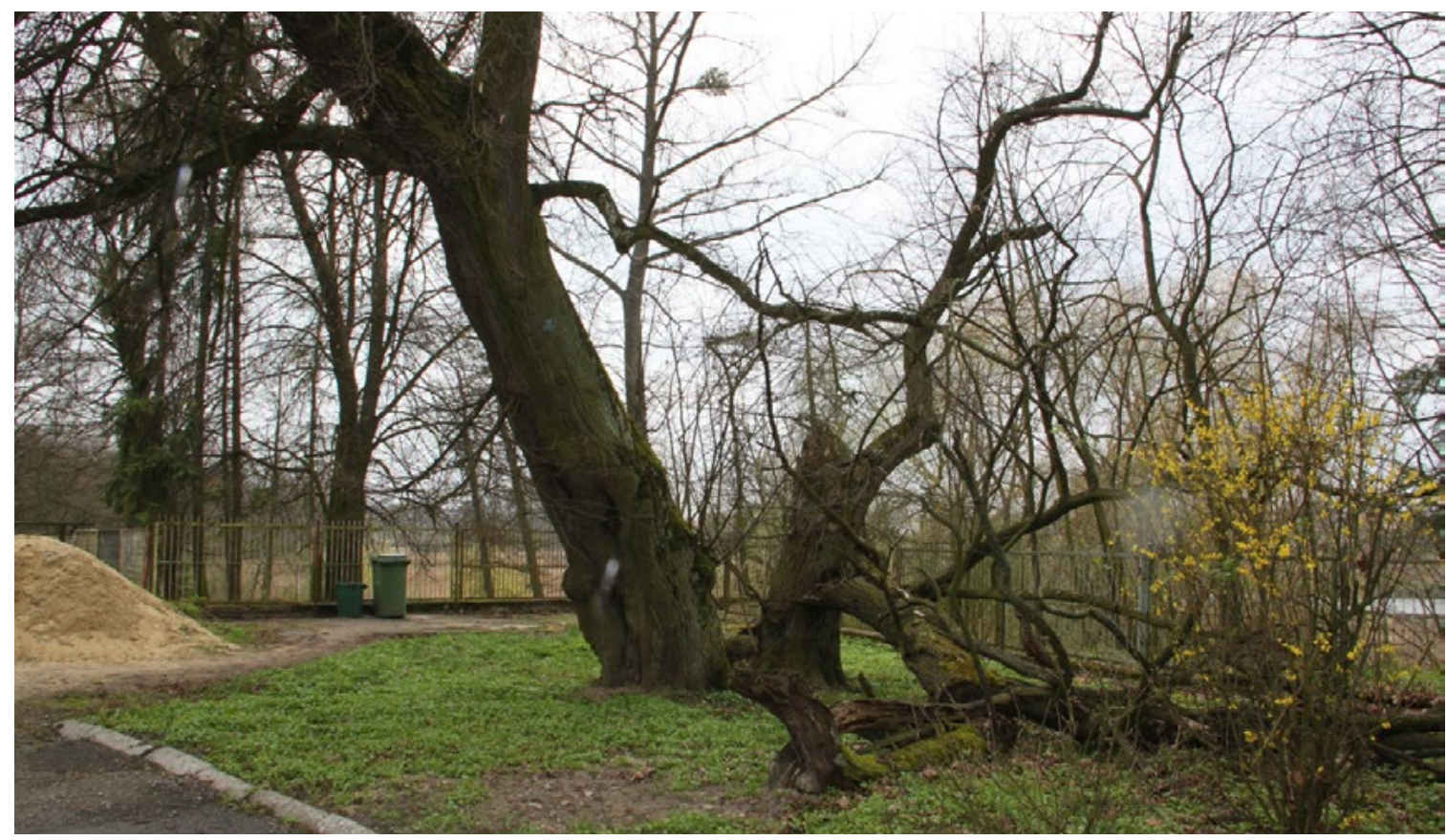

Ryc. 6. Tilia cordata Mill. w sektorze pierwszym o obwodzie $376 \mathrm{~cm}$, będące pomnikiem przyrody, przeznaczone do zabiegów pielęgnacyjnych. Fot. K. Boguszewska, 2016.

Tilia cordata Mill. in first sector - diameter of the tree $376 \mathrm{~cm}$, monumental tree for treatments, Photo by K. Boguszewska, 2016.
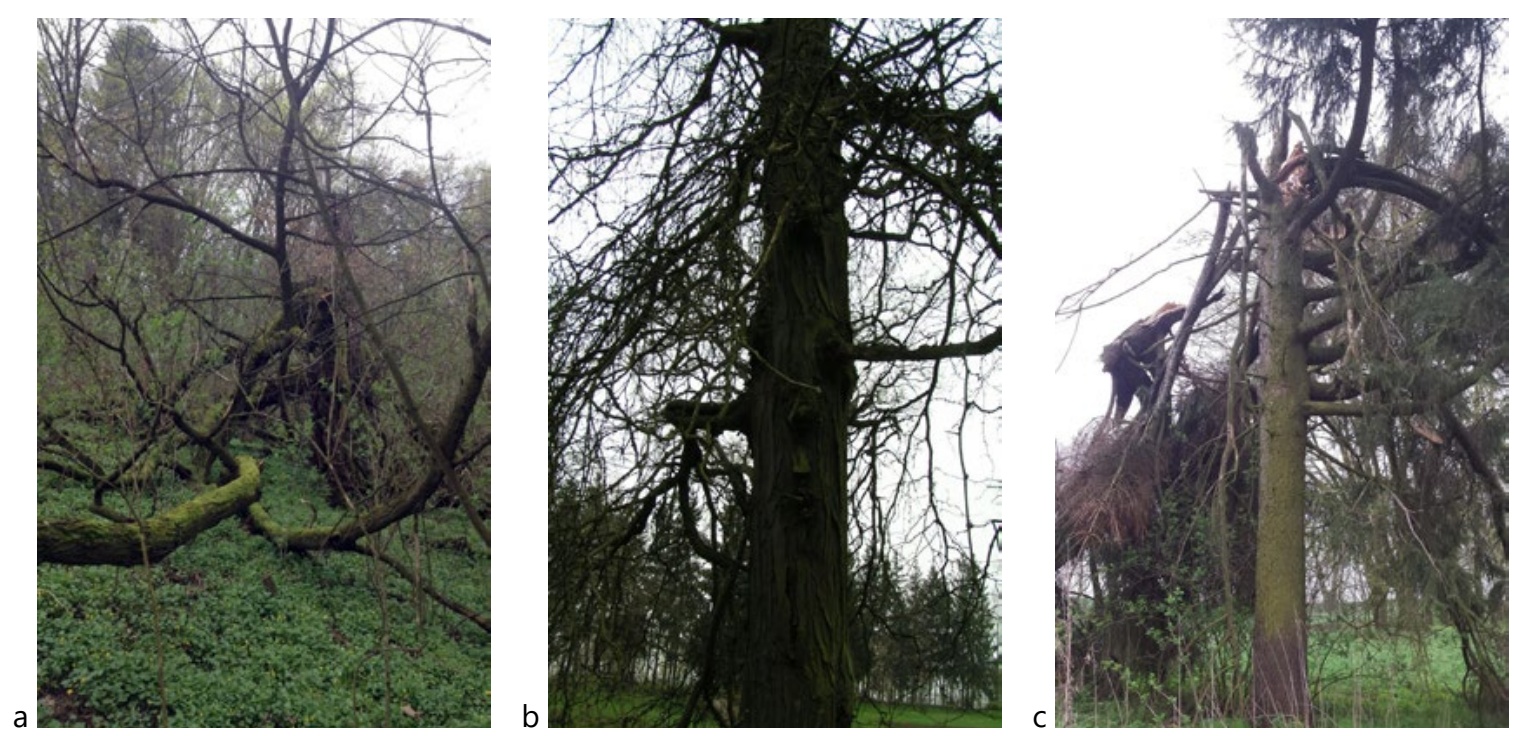

Ryc. 7. a - drzewo, w sektorze nr 4 - Tilia cordata Mill. będące pomnikiem przyrody, przeznaczone do usunięcia, b-Glediczja trójcierniowa o obwodzie pnia $122 \mathrm{~cm}, \mathrm{c}$ - Drzewo w sektorze nr 2 - Picea abies (L.) H.Karst ze złamanym przewodnikiem, przeznaczone do usunięcia. Fot. Kamila Boguszewska, 2016.

a - tree in sector 4, Tilia cordata Mill.monumental tree for removal, b- Gleditsia triacanthos, diameter 122, c- tree in second sector - Picea abies (L.)H. Karst, with broken trunks for removal, photo by Kamila Boguszewska, 2016. 
We wcześniejszych opracowaniach wykazano wiele gatunków cennych i egzotycznych, które posadzone były w części krajobrazowej parku. Były to miedzy innymi: dąb błotny (Querqus palustris $-2,7 \mathrm{~m}$ pierśnica, kasztanowiec czerwony (Aesculus rubra 2,4 m) czy sosna wejmutka (Pinus strobus $-2,6 \mathrm{~m})^{10}$. Niestety drzewa te nie zachowały się do chwili obecnej. Podobnie jak zinwentaryzowany w sektorze pierwszym wykrot dębu czerwonego (Quercus rubra L.). Drzewo to było jedynym egzemplarzem tego gatunku w parku. Posiadało ono znaczący obwód pnia i stanowiło nasadzenie soliterowe, istotne dla układu kompozycyjnego parku.

Cennym drzewem wykazywanym wcześniej w inwentaryzacjach przez M. Kseniaka i E. Podkościelny jest glediczja trójcierniowa Gleditsia triacanthos L. o obwodzie $240 \mathrm{~cm}$ w pierśnicy (ryc. 3 b). Drzewo to szacowane jest na około 122 lata. Zlokalizowana jest ona w sąsiedztwie pomnikowego dębu szypułkowego. Stanowi ona nasadzenie soliterowe i charakteryzuje się dobrym stanem zdrowotnym.

\section{Szpalery i aleje parkowe}

Charakterystycznymi elementami parku są nasadzenia alejowe, szpalerowe i grupowe. W części rezydencjonalnej na uwagę zasługuje główna aleja dojazdowa do pałacu obsadzona kasztanowcami białymi (Aesculus hippocastanum L.) i egzemplarzami lipy drobnolistnej (Tilia cordata Mill). Niektóre z drzew datowane są na ponad 200 lat. Pierwotnie była to w całości aleja obsadzana lipami podobnie jak wschodnia granica parku wyznaczona w przeszłości szpalerem drzew tego gatunku. Obecnie szpalery charakteryzują się one dużą nieregularnością oraz młodym podrostem z gatunku Prunus $s p$. W najbliższym sąsiedztwie pałacu wyróżniają się nasadzenia wtórne w formie świerkowego szpaleru. Nasadzenia te są niespójne z historycznym charakterem obiektu i tworzą kolizje kompozycyjne i przestrzenne, jednak są faktem i świadectwem historii w ostatnim półwieczu.

W części krajobrazowej parku na uwagę zasługują nasadzenia grupowe w postaci „żywych altan'. Bardzo charakterystyczna jest grupa pięciu dębów szypułkowych (Quercus robur L.) drzewa te szacowane są na około 150 lat. Oprócz nich mamy także nasadzenia z grabu pospolitego (Carpinus betulus L.) dwie grupy robinii akacjowej (Robinia pseudoacacia L.), stanowiące istotne elementy kompozycyjnym parku. We wschodniej części założenia znajdują się starodrzewy w postaci szpalerów grabowych (Carpinus betulus L.) Ich stan zachowania jest dobry, a forma przestrzenna którą tworzą czytelna w przestrzeni parku. Brak wieloletnich cięć pielęgnacyjnych doprowadził jednak do zbytniego rozrostu koron poszczególnych drzew oraz wypadania pojedynczych egzemplarzy, przez co szpalery charakteryzuje nieregularnośćc ${ }^{11}$.

\section{Podsumowanie}

Pomimo upływających lat kompozycja parku krajobrazowego w Krzesimowie jest nadal czytelna. Na jego terenie można nadal odnaleźć zabytkowy drzewostan tworzący układy szpalerowe i alejowe. Część drzew stanowią: nasadzenia soliterowe - obecnie w większości pomniki przyrody lub grupowe - w formie żywych altan.

Ogólny stan drzewostanu parkowego określa się jako dobry pomimo iż na terenie parku obserwuje się drzewa z martwymi konarami, posuszem w koronie czy rozległymi ubytkami pnia oraz postępującą destrukcją drewna.

$\mathrm{Na}$ obszarze opracowania zinwentaryzowano 42 egzemplarze drzew jako martwe, wśród nich 3 sztuki to wykroty, które należy usunąć i uporządkować teren. Sto czterdzieści dwa egzemplarze drzew zakwalifikowano do leczenia, zaś sto czterdzieści trzy do usunięcia z powodu złej kondycji zdrowotnej, zniekształconej budowy przewodnika i korony czy drzew będących nasadzeniami wtórnymi bądź najmłodszymi samosiewami. Sukcesywnie i wybiórczo należy też usuwać z terenu parku nadmierne zagęszczenie podrostów drzew liściastych, pochodzących z naturalnego odnowienia. 


\section{Bibliografia}

[1] K. Boguszewska, M. Boguszewska, R. Chyżewska, M. Boruch, J. Myśliwiec, Zespót pałacowo-parkowy w Krzesimowie część druga gospodarka drzewostanem, s. 1-20, maj 2016, (archiwum autora)

[2] K. Boguszewska, M. Boguszewska, R. Chyżewska, M. Boruch, J. Myśliwiec, Zespót pałacowo-parkowy w Krzesimowie część pierwsza Szczegółowa inwentaryzacja dendrologiczna, s. 1-9, maj 2016, (archiwum autora)

[3] M. Dudkiewicz, Koncepcja rewaloryzacji zabytkowego założenia pałacowo-parkowego w Krzesimowie w gminie Mełgiew, Acta Sci. Pol. Formatio Circumiectus. 12 (4), 2013

[4] M. Kseniak, Parki i ogrody dworskie w Województwie Lubelskim cz. I, Od Trawnik do Łęcznej wzdłuż Wieprza, PTTK Zarząd Wojewódzki, Lublin 1981

[5] E. Podkościelny, A. Chrzanowska, Krzesimów gmina Mełgiew, woj. lubelskie, Projekt rewaloryzacji zabytkowego założenia pałacowo-parkowego, Warszawa - Lublin, 2003 (archiwum WUOZ/ Lublin)

[6] Wytyczne konserwatorskie do planowanego remontu budynków i rewaloryzacji parku., Wojewódzki Urząd Ochrony Zabytków, IN.5183.30.1.2016

[7] Śladami przeszłości gminy Mełgiew, Zespół pałacowo-parkowy w „Dolina Krzyży: w Krzesimowie, Krzesimów 2016

[8] Plan gruntów majątku Krzesimów autorstwa mierniczego przysięgłego Leopolda Pajdowskiego z roku 1935 (Archiwum Sądu Okręgowego w Lublinie, Lublin wschód)

\section{Park compostion and its state of preservation in the palace-park complex in Krzesimow in Lubelskie Voivodship}

Summary: The palace-park complex in Krzesimow located is in the eastern part of the municipality of Melgiew about 20 kilometers from Swidnik. Nowadays, it consists of the residential part ( the "palace on the island) and a park dated back to $19^{\text {th }}$ centaury. The first mention of the residential area dates back to the $16^{\text {th }}$ century. In $19^{\text {th }}$ century, when the Stamirowski family owned the property, the park and the preserved buildings were built.

In 2016 the detailed dendrological inventory and a tree management project were carried out. It was the first time when the documentation was made on the map for design. It covered eight hectares of the park along with the alleys. The paper presents the results of the studies in the context of park composition and its state of preservation.

Keywords: Krzesimow, park, composition, dendrological inventory 